\title{
Hubungan Terhadap Tingkat Pendidikan dan Pekerjaan dengan Penyalahguna Napza
}

\section{Relationship between The level of Education and work withidus}

\author{
Matwimiyadi
}

\section{Rumah Sakit Jiwa Tampan Pekanbaru}

\begin{abstract}
ABSTRAK
Penyalahguna NAPZA adalah orang yang menggunakan salah satu atau beberapa jenis Narkotika, Psikotropika dan Zat Adiktif Lain(NAPZA), secara berkala atau teratur diluar indikasi medis, sehingga menimbulkan gangguan kesehatan fisik, psikis dan gangguan fungsi sosial. Di Indonesia prevalensi penyalahgunaan NAPZA mengalami peningkatan setiap tahun dan diperkirakan 3,6 juta orang terlibat dalam penyalahgunaan NAPZA. Di Provinsi Riau jumlah penyalahguna NAPZA terus mengalami peningkatan dari tahun 2008 s/d 2010.Rumah Sakit Jiwa Tampan Provinsi Riau merupakan satu-satunya rumah sakit pemerintah di Provinsi Riau yang menyelenggarakan perawatan pada penyalahguna NAPZA. Penelitian ini bertujuan untuk mengetahui hubungan terhadap tingkat pendidikan dan pekerjaan dengan penyalahguna NAPZA.Jenis penelitian ini adalah kuantitatif analitik observasional dengan menggunakan desain case-control. Populasi penelitian ini adalah seluruh pasien yang berkunjung ke RSJ Tampan Provinsi Riau tahun 2009 s/d 2010. Sampel kasus adalah penyalahguna NAPZA yang berjumlah 87 kasus dan sampel kontrol sebanyak 87 diambil dengan teknik simple random sampling. Pengumpulan data sekunder dilakukan dengan cara penelusuran dokumen terhadap kartu status penyalahguna NAPZA di bagian Rekam Medik. Analisa data dilakukan secara univariat dan bivariat. Hasil penelitian ini adalah pekerjaan (OR adjusted : 1,93; 95\% C.I : 1,053,55).Dari hasil penelitian ini menunjukan bahwa orang yang tidak bekerja berpeluang 1,93 kali lebih besar menjadi penyalahguna NAPZA dibandingkan dengan orang yang bekerja. Disarankan kepada RSJ Tampan Provinsi Riau agar lebih meningkatkan promosi kesehatan kepada masyarakat, berkaitan dengan pencegahan penyalahgunaan NAPZA.
\end{abstract}

Kata Kunci : RSJ Tampan Provinsi Riau, Tingkat Pendidikan dan Pekerjaan, Penyalahguna NAPZA.

\begin{abstract}
Drug abusers are people who use one or several types of Narcotics, Psychotropic and Other Addictive Substances, periodically or regularly outside the medical indications, giving rise to health problems of physical, psychological and social dysfunction. In Indonesia prevalence of drug abuse has increased every year and expected 3.6 million people are involved in drug abuse.This study aimed to determine the relationship of the level of education and work with drug abusers. This research is using a quantitative analytical observational case-control design. The population of this study were all patients who visited a mental hospital Riau province.The sample cases are drug abusers who totaled 87 cases and control samples as much as 87 taken by simple random sampling technique. Secondary data collection is done by tracking the status of the document to the card of drug abuse in the medical record.The data were analyzed using univariate and bivariate.The result of this research is the work (adjusted OR: 1.93; 95\% CI: 1.05 to 3.55).From the results of this study showed that people who do not work with 1.93 times greater chance of becoming drug abusers compared with those who to work. It is recommended to RSJ Handsome Riau Province in order to further enhance the promotion of public health, with regard to the prevention of drug abuse.
\end{abstract}

Keywords: Tampan Pschiatric Hospital Riau Province, Level of Education and Employment, drug abusers

\section{PENDAHULUAN}

Penyalahgunaan menyalahgunakan salah satu atau beberapa jenis Narkotika, Psikotropika dan Zat Adiktif Lain (NAPZA), secara berkala atau teratur diluar indikasi medis, sehingga menimbulkan gangguan kesehatan fisik, psikis dan gangguan fungsi sosial. Sedangkan penyalahguna NAPZA adalah orang yang menggunakan NAPZA tanpa sepengetahuan dan pengawasan dokter, hanya ingin menikmati efek sampingnya saja bukan mengharapkan efek pengobatannya dan merupakan tindakan melawan hukum (Depkes, 2001).
Di seluruh Dunia, penyalahgunaan NAPZA menunjukan peningkatan dari tahun ke tahun. Dilaporkan, 5 persen dari total populasi dunia pernah mencoba NAPZA, dan kini ada sekitar 27 juta orang yang kecanduan dan mengalami masalah dengan penyalahgunaan NAPZA. Kematian akibat NAPZA diperkirakan sekitar 200.000 orang per tahun(Mere, 2011). Di Indonesia, penyalahgunaan NAPZA terus mengalami peningkatan dari tahun 2007 hingga tahun 2011. Pada tahun 2007 prevalensi penyalahgunaan NAPZA sebesar 1,5 atau sekitar 2,9 hingga 3,2 juta Orang dan pada tahun 2011, meningkat menjadi 2,8 per jumlah penduduk usia 10 hingga 58 tahun. Tahun 2010 diperkirakan 3,6 juta orang

Alamat Korespodensi : Matwimiyadi, RSJ Tampan, J1 HR Soeberantas, Pekanbaru, HP: 08127650617 
menjadi penyalahguna NAPZA dan angka itu sekitar 15 ribu orang harus meregang nyawa setiap tahun karena penyalahgunaanNAPZA. Angka itu juga belum termasuk mereka yang terkena dampak lain akibat penyalahgunaanNAPZA, Lebih dari 500 ribu orang positif terkena Human Immunodeficiency Virus (HIV) dan Acquired Immune Deficiency Syndrome(AIDS), yang menjadi salah satu penyakit penyebab kematian terbesar di dunia(Mere, 2011).

Di Provinsi Riau, berdasarkan laporan dari 35 rumah sakit yang melakukan monitoring terhadap penyalahgunaan NAPZA dapat diketahui bahwa, terjadi peningkatan penyalahgunaan NAPZA dari tahun 2008 hingga tahun 2010, yaitu sebanyak 361 kasus pada tahun 2008 meningkat menjadi 499 kasus pada tahun 2009 dan terus meningkat menjadi 596 kasus pada tahun 2010 (Dinkes Provinsi Riau, 2010).

Ada keterkaitan antara penyalahgunaan NAPZA dengan kejadian HIV/AIDS. Penggunaan NAPZA terutama yang mengunakan suntikan sangat berisiko tertular HIV/AIDS.Ketika pengguna berbagi NAPZA dengan peralatan suntik atau menggunakan peralatan yang tidak seteril, maka HIV dapat ditularkan di antara pengguna. Infeksi lain-seperti hepatitis $\mathrm{C}$ juga dapat menyebar dengan cara ini. Penyalahgunaan NAPZA dengan metode apapun (bukan hanya suntik) dapat membuat seseorang berisiko tertular HIV (Sunarno,2007).

Banyak faktor yang dapat mempengaruhi seseorang untuk menjadi penyalahguna NAPZA, diantaranya adalah faktor individu, lingkungan dan NAPZA itu sendiri. Dari beberapa faktor tersebut, faktor individu (umur, pekerjaan dan pendidikan) mempunyai perananan penting yang dapat mempengaruhi seseorang untuk menyalahgunakan NAPZA (BNN, 2007d).

Di Rumah Sakit Jiwa (RSJ) Tampan Provinsi Riau terjadi fluktuasi kunjungan penyalahguna NAPZA dari tahun 2008 hingga tahun 2010. Dimana pasien penyalaguna NAPZA yang berkunjung pada tahun 2008 sebanyak 80 kasus, menurun pada tahun 2009 menjadi 48 kasus dan pada tahun 2010 terjadi peningkatan lagi menjadi 54 kasus. Rumah Sakit Jiwa Tampan Provinsi Riau merupakan satu-satunya rumah sakit Pemerintah di Provinsi Riau yang menyelenggarakan perawatan pada penyalahguna NAPZA. Tujuan penelitian ini adalah diketahuinya hubungan terhadap tingkat pendidikan dan pekerjaan dengan penyalahguna NAPZA yang berkunjung ke RSJ Tampan Provinsi Riau.

\section{METODE PENELITIAN}

Jenis penelitian ini merupakan penelitian kuantitatif analitik observasional dengan menggunakan pendekatan kasus kontrol (case-control study). Besar sampel dalam penelitian ditentukan dengan melakukan perhitungan berdasarkan formula besar sampel untuk uji hipotesis odds ratio, yang merupakan pengembangan dari formula besar sampel untuk uji hipotesis beda dua proporsi.

Populasi dalam penelitian ini adalah seluruh pasien yang berkunjung ke Rumah Sakit Jiwa (RSJ) Tampan Provinsi Riau tahun 2009 s.d 2010 yang berjumlah 55210 pasien. Sampel dalam penelitian ini menggunakan perbandingan 1 kasus : kontrol. Sampel kasus adalah pasien penyalahguna NAPZA yang berkunjung ke RSJ Tampan Provinsi Riau tahun 2009 s.d 2010 yang berjumlah 87pasin yang diambil menggunakan tekhnik total sampel. Sedangkan sempel kontrol adalah pasien yang berkunjung ke RSJ Tampan Provinsi Riau tahun 2009 s.d 2010 dan bukan penyalahguna NAPZA yang berjumlah 55.21087 (kasus) $=55.123$. Untuk perbandingan kontrol sebanyak 87diambil dengan menggunakan tekhnik acak sederhana (simpel radom sampling) menggunakan tabel acak. Dengan demikian jumlah sampel dalam penelitian ini berjumlah 87 kasus +87 kontrol $=174$ sampel.

Untuk mengetahui signifikansi hubungan antara variabel independent dan satu variabel dependent dan sekaligus menghitung besarnya risiko terjadinya penyalahgunaan NAPZA menggunakan indikator nilai Odds Ratio (OR), yang diuji menggunakan uji Chi Square dengan CI 95\%.

\section{HASIL PENELITIAN}

\section{Analisis Univariat}

Berdasarkan hasil analisa univariat pada tabel 1 menunjukkan bahwa, dari 87 kasus terbanyak berpendidikan SLTA, yaitu sebanyak $38(43,7 \%)$ dan dari 87 kontrol terbanyak juga berpendidikan SLTA yaitu sebanyak 35(40,2\%). Sedangkan berdasarkan pekerjaan, dari 87 kasus sebagian besar tidak bekerja, yaitu sebanyak 56(64,4\%) dan dari 87 kontrol sebagian besar juga tidak bekerja, yaitu sebanyak 42(48,3\%).

\section{Analisis Bivariat}

Pada tabel 2 dapat dilihat hasil analisa keeratan hubungan antara tingkat pendidikan dengan penyalahguna NAPZA, diperoleh nilai $\mathrm{OR}=1,51$, artinya orang yang berpendidikan rendah berpeluang 1,51 kali untuk menjadi penyalahguna NAPZA dibanding dengan orang yang berpendidikan tinggi. Dari nilai OR diatas dapat disimpulkan bahwa, tingkat pendidikan merupakan faktor risiko terjadinya penyalahguna NAPZA walaupun keeratan hubungannya sangat lemah. Hasil uji statistik menggunakan Uji Chi Square dengan alpha (5\%) diperoleh nilai $\mathrm{p}=0,225$, dengan demikian nilai plebih besar dari alpha sehingga Ha ditolak. Maka dapat disimpulkan bahwa, tidak ada perbedaan yang signifikan proporsi penyalahguna NAPZA antara 
orang yang berpendidikan rendah dengan orang yang berpendidikan tinggi.

Berdasarkan hasil analisa keeratan hubungan antara pekerjaan dengan penyalahguna NAPZA diperoleh nilai $\mathrm{OR}=1,93$, artinya orang yang tidak bekerja berpeluang 1,93 kali untuk menyalahgunakan NAPZA dibandingkan dengan orang yang berkerja. Berdasarkan dari nilai OR tersebut juga dapat disimpulkan bahwa, pekerjaan merupakan faktor risiko terjadinya penyalahguna NAPZA. Hasil uji statistik menggunakan Uji Chi Square dengan alpha (5\%) diperoleh nilai $p=0,047$, dengan demikian nilai plebih kecil dari alpha sehingga Ha diterima. Maka dapat disimpulkan bahwa, ada perbedaan yang signifikan proporsi penyalahgunaNAPZA antara orang yang tidak bekerja dan orang yang bekerja
Tabel 1

Distribusi Penyalahguna NAPZA Berdasarkan Pendidikan dan Pekerjaan

\begin{tabular}{lrrrr}
\hline \multirow{2}{*}{$\begin{array}{l}\text { Karakteristik } \\
\text { Responden }\end{array}$} & \multicolumn{4}{c}{ Jumlah } \\
\cline { 2 - 5 } & \multicolumn{2}{c}{ Kasus } & Kontrol \\
\cline { 2 - 5 } Pendidikan & & & & N $\%$ \\
a. Tidak tamat SD & 3 & 3,4 & 5 & 5,7 \\
b. SD & 19 & 21,8 & 16 & 18,4 \\
c. SLTP & 25 & 28,7 & 17 & 19,9 \\
d. SLTA & 38 & 43,7 & 35 & 40,2 \\
e. PT & 2 & 2,3 & 14 & 16,1 \\
\hline$\quad \quad$ Jumlah & 87 & 100 & 87 & 100 \\
\hline Pekerjaan & & & & \\
a. Tidak bekerja & 56 & 64,4 & 42 & 48,3 \\
b. Swasta & 11 & 12,6 & 20 & 23,0 \\
c. Wirausaha & 11 & 12,6 & 4 & 4,6 \\
d. PNS & 2 & 2,3 & 10 & 11,5 \\
e. TNI/Polri & 3 & 3,4 & 1 & 1,1 \\
f. Petani & 3 & 3,4 & 9 & 10,3 \\
g. Buruh & 1 & 1,1 & 1 & 1,1 \\
\hline$\quad \quad$ Jumlah & 87 & 100 & 87 & 100 \\
\hline
\end{tabular}

Tabel 2

Hubungan Tingkat Pendidikan dan Status Pekerjaan terhadapPenyalahguna NAPZA

\begin{tabular}{|c|c|c|c|c|c|c|}
\hline \multirow[t]{2}{*}{ Variabel } & \multicolumn{2}{|c|}{$\begin{array}{c}\text { Penyalahguna } \\
\text { NAPZA }\end{array}$} & \multicolumn{2}{|c|}{$\begin{array}{c}\text { Bukan } \\
\text { Penyalahguna } \\
\text { NAPZA } \\
\end{array}$} & \multirow[t]{2}{*}{ Nilai P } & \multirow[t]{2}{*}{$\begin{array}{c}\text { OR } \\
(95 \% \mathrm{CI})\end{array}$} \\
\hline & $\mathrm{N}$ & $\%$ & $\mathrm{~N}$ & $\%$ & & \\
\hline \multicolumn{7}{|l|}{ Tingkat Pendidikan } \\
\hline Pendidikan Rendah & 47 & 54 & 38 & 43,7 & \multirow{3}{*}{0,225} & \multirow{3}{*}{$\begin{array}{c}1,51 \\
(0.83-2,75)\end{array}$} \\
\hline Pendidikan Tinggi & 40 & 46 & 49 & 56,3 & & \\
\hline Jumlah & 87 & 100 & 87 & 100 & & \\
\hline \multicolumn{7}{|l|}{ Pekerjaan } \\
\hline Tidak Bekerja & 56 & 64,4 & 42 & 12 & \multirow{3}{*}{0,047} & \multirow{3}{*}{$\begin{array}{c}1.93 \\
(1,05-3,55)\end{array}$} \\
\hline Bekerja & 31 & 36,6 & 45 & & & \\
\hline Jumlah & 87 & 100 & 87 & 100 & & \\
\hline
\end{tabular}

\section{PEMBAHASAN}

Pekerjaan merupakan faktor risiko terjadinya penyalahguna NAPZA. Orang yang tidak bekerja lebih berisiko menjadi penyalahguna NAPZA dibanding dengan orang yang bekerja. Orang yang tidak bekerja mempunyai dorongan yang kuat untuk mendapatkan pekerjaan guna mendapatkan penghasilan tanpa harus bekerja keras, tanpa modal dan investasi.Sehingga tidak sedikit orang yang terjerumus kedalam penyalahgunaan NAPZA dengan bersedia menjadi pengedar (trafficker) NAPZA untuk mendapatkan penghasilan yang besar.

Menurut BNN (2004) menyatakan bahwa, orang yang tidak bekerja tentu mempunyai beban perekonomian dan beban psikologis yang sangat berat, hal tersebut tentu dapat menimbulkan ketegangan jiwa sehingga tidak mustahil akan mencari pelarian dari masalah dan mencari ketenangan jiwa dengan mengkonsumsi NAPZA. Selain itu, orang yang tidak bekerja mempunyai banyak waktu luang yang memungkinkan seseorang untuk mengisi waktu luang tersebut dengan menyalahgunakan NAPZA.

Menurut hemat peneliti, masyarakat perlu mempunyai pekerjaan yang tetap sehingga mempunyai penghasilan dan aktifitas yang rutin. Dengan pekerjaan tetap, masyarakat dapat terhindar dari permasalahan ekonomi yang dapat menimbulkan ketegangan jiwa dan waktu luang dapat diisi dengan bekerja, tidak diisi dengan tindakan menyalahgunakan NAPZA.

\section{KESIMPULAN}

Berdasarkan hasil penelitian dapat disimpulkan bahwa, Orang yang tidak bekerja berpeluang 1,93 kali menjadi penyalahguna NAPZA dibandingkan dengan orang yang berkerja, dan didukung dengan adanya hubungan yang bermakna secara statistik.

\section{SARAN}

Berdasarkan hasil penelitian, pembahasan dan kesimpulan maka diharapkan kepada Rumah Sakit 
Jiwa Tampan Provinsi Riau, untuk dapat meningkatkan promosi kesehatan kepada masyarakat, tentang foktor-faktor yang berhubungan dengan penyalahgunaan NAPZA dan diharapkan agar petugas Rekam Medik menfalidkan format penyalahgunaan NAPZA dengan baik dan benar.

\section{UCAPAN TERIMA KASIH}

Ucapan terima kasih ditujukan kepada dr. H. Zainal Abidin, MPH selaku Ketua Sekolah Tinggi Ilmu Kesehatan (STIKes) Hang Tuah Pekanbaru, Emy Leonita, SKM. MPHselaku Ketua Program Studi Ilmu Kesehatan Masyarakat STIKes Hang Tuah Pekanbaru, Hj. Tin Gustina, SKM, M.Kesselaku dosen Pembimbing I, Bapak Chairunnas, SKM selaku dosen pembimbingII, dr. Maisarah, Sp.Kjselaku dosen penguji, dan dr.Mursal Amir selaku Direktur Rumah Sakit Jiwa Tampan Provinsi Riau.

\section{DAFTAR PUSTAKA}

Ariawan, A(1998). Besar dan metode sampel pada penelitian kesehatan, Jakarta: Universitas Indonesia.

BNN, (2004). Pedoman Pencegahan Penyalahgunaan Narkoba Bagi Pemuda, Jakarta: Badan Narkotika Nasional Republik Indonesia.

(2007a). Mengenal Penyalahgunaanan Narkoba, Buku 2A Untuk Remaja/Anak Muda. Jakarta: Badan Narkotika Nasional Republik Indonesia.

(2007b) Mengenal Penyalahgunaanan Narkoba, Buku 2B Untuk orang Tua dan Remaja. Jakarta: Badan Narkotika Nasional Republik Indonesia.

(2007c), Pencegahan Lebih Baik Dari Pada Mengobati. Jakarta: Badan Narkotika Nasional Republik Indonesia.

(2007d). Advokasi Pencegahan Penyalahgunaanan Narkoba. Jakarta: Badan Narkotika Nasional Republik Indonesia.
(2008) Advokasi Pencegahan Penyalahgunaanan Narkoba. Jakarta: Badan Narkotika Nasional Republik Indonesia.

Dinkes Prov Riau, (2010). Lakip Dinas kesehatan provinsi Riau tahun 2010.

Depkes, (2001).Pedoman Praktis Bagi Petugas Kesehatan (Puskesmas) Mengenai Penyalahgunaan Narkotika, Psikotropika dan Zat Adiktif Lain (NAPZA).

Hikmat, (2007), Awas Narkoba, Para Remaja Waspadalah. Bandung: Grafitri.

Ilyas, (2009).wajib belajar 9 tahun, http://ilyasismailputrabugis.Diakses : jumat, 25 Pebruari 2011.

Jaji, (2009),Hubungan Faktor Sosial Dan Spiritual Dengan Risiko Penyalahgunaan NAPZA Pada Remaja SMP dan SMA di Kota Palembang.http://eprints.unsri.ac.id

Lapau, B. (2007). Prinsip dan Metode Epidemiologi, Jakarta: Uhamka Press.

Murti, B (2006). Desain dan Ukuran Sampel Untuk Penelitian Kuantitatif dan Kualitatif Dibidang Kesehatan, Yogyakarta: Gajah Mada University Press.

Mere, (2011). PrevalensiPenyalahgunaan Narkoba di Indonesia.

http://www.suarapembaruan.com.

RSJ Tampan, (2010). Lakip Ruamah Sakit Jiwa Tampan Provinsi Riau Tahun 2010.

Sunarno,(2007), Narkoba, Bahaya dan Upaya pencegahan. Semarang: Bengawan Ilmu.

Tanjung, A. (2010). Biostatistik Inferensial, Bandung: Tantaramesta.

UUD No 35 Tahun 2009 Tentang Narkotika, http://asaborneo.blogspot.com

Diakses : Kamis, 28 April 2011. Pukul 21.00 WIB. 